\title{
Assessing the Capabilities of Three Regional Climate Models over CORDEX Africa in Simulating West African Summer Monsoon Precipitation
}

\author{
A. A. Akinsanola, K. O. Ogunjobi, I. E. Gbode, and V. O. Ajayi \\ Department of Meteorology and Climate Science, Federal University of Technology, PMB 704, Akure, Ondo State, Nigeria \\ Correspondence should be addressed to A. A. Akinsanola; mictomi@yahoo.com
}

Received 26 January 2015; Revised 24 April 2015; Accepted 11 May 2015

Academic Editor: Stephen J. Colucci

Copyright (C) 2015 A. A. Akinsanola et al. This is an open access article distributed under the Creative Commons Attribution License, which permits unrestricted use, distribution, and reproduction in any medium, provided the original work is properly cited.

\begin{abstract}
This study evaluates the ability of three Regional Climate Models (RCMs) used in Coordinated Regional Climate Downscaling Experiment (CORDEX) to simulate the characteristics of rainfall pattern during the West Africa Summer Monsoon from 1998 to 2008. The seasonal climatology, annual rainfall cycles, and wind fields of the RCMs output were assessed over three homogenous subregions and validated using precipitation data from eighty-one (81) ground observation stations and TRMM satellite data. Furthermore, the ability of the RCMs to simulate response to El Nino and La Nina events was assessed. Results show that two of the RCMs (RCA and REMO) simulated the main features of the rainfall climatology and associated dynamics over the three subregions (Guinea Coast, Savannah, and Sahel) of West Africa. The RCMs also capture the African Easterly Jet (AEJ) and Tropical Easterly Jet (TEJ) with little variations in position and intensity. Analysis shows significant biases in individual models depending on subregion and season under consideration which may be attributed to strong cyclonic circulation observed at $850 \mathrm{mb}$ pressure level. In general, the study shows RCA and REMO fairly simulate West Africa rainfall adequately and can therefore be used for the assessment of West African Summer Monsoon and future climate projections.
\end{abstract}

\section{Introduction}

The West African Monsoon (WAM) is one of the most crucial and dynamic phenomena of the West African climate system during the summer period [1]; it plays a vital role in producing majority of the annual precipitation in the region. This monsoon has a large effect on weather and climate anomalies at both local and global scales due to its strong dependence on regional and global Sea Surface Temperature (SST) variations [2-4]. The WAM is caused by the seasonal reversal of winds due to differential heating between land and ocean, thereby resulting in seasonal heavy precipitation patterns. Previous studies have shown that the rainfall distribution over West Africa is critical for many activities such as water resources monitoring, rainfed agriculture, and drought and flood forecasting [5]. The WAM system consists of many atmospheric features such as monsoon flow, African Easterly Jet (AEJ), Tropical Easterly
Jet (TEJ), African Easterly Waves (AEWs), and Mesoscale Convective Systems (MCSs) interacting in a complex way to provide the summer monsoon rainfall [1]. In West Africa, two low-level westerly flow regimes are important for the moisture transport; first is the well-known West African monsoon flow, which is formed by the westward acceleration of the onshore flow across the Guinean Coast. The second is the westerly flow near $10^{\circ} \mathrm{N}$, directed from the eastern Atlantic onto the West African coast. This westerly flow was identified firstly by [6] using high-resolution scatterometer measurements and its dynamics were studied. However [7] named this jet the West African Westerly Jet (WAWJ) owing to its distinguished features and dynamics from the WAM flow. Recently, this WAMJ has been defined as a low-level feature of the summer climatology that transports moisture from the eastern Atlantic onto the African continent [8]. Previous studies have established a relationship between the WAMJ and rainfall variability over Sahelian part of West 


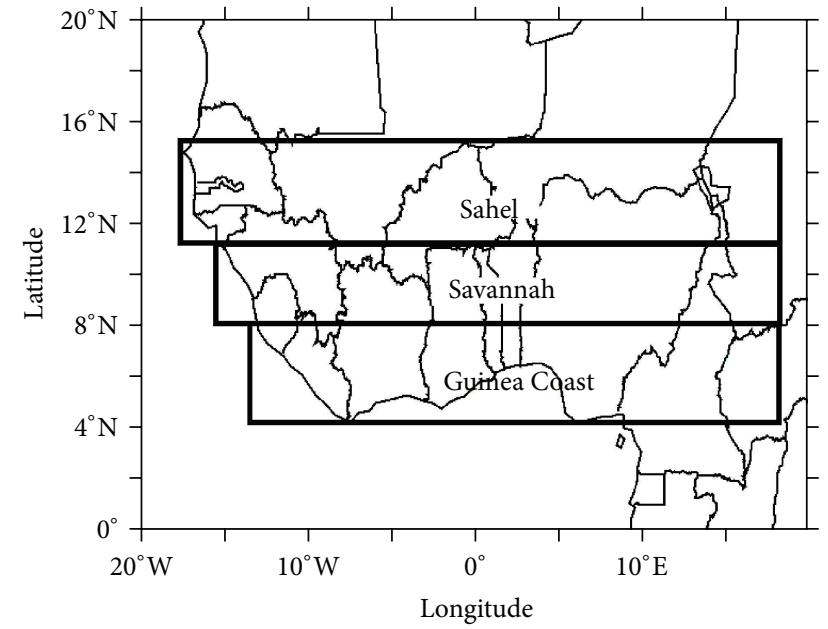

Figure 1: West African domain divided into three climatic zones: Guinea $\left(4^{\circ} \mathrm{N}-8^{\circ} \mathrm{N}\right)$, Savanna $\left(8^{\circ} \mathrm{N}-11^{\circ} \mathrm{N}\right)$, and Sahel $\left(11^{\circ} \mathrm{N}-16^{\circ} \mathrm{N}\right)$ (source: $[49,50]$ ).

Africa. For example, [8] reported that wet and dry Sahel is associated with strong and weak WAMJ, respectively. In the mid-troposphere around $700-600 \mathrm{hPa}$ there exists a strong easterly moisture flux associated with the African Easterly Jet (AEJ) centered near $15^{\circ} \mathrm{N}$ which advects moisture from eastern and central Africa to the west [6]. The AEJ occurs as a result of strong meridional surface moisture and temperature gradients between the Sahara and equatorial Africa $[8,9]$ and is associated with vertical wind shear. These gradients sustain an easterly shear that is strong enough to establish the AEJ above the lower-tropospheric westerly monsoon flow. However, owing to its importance, the Jet has been ascertained as one of the most crucial factors for Mesoscale Convective Systems development, sustenance, and movement over West Africa. Furthermore, the TEJ which is a June to September phenomenon is located in the upper troposphere around $250-200 \mathrm{hPa}$ centered near $10^{\circ} \mathrm{N}$ and occurs as a result of mass flux from the Himalayas (Asia) and it has been reported by [8] that it only has a modulating effect on the WAM while the AEW is a synoptic activity which poses fast mode variability on rainfall $[10,11]$ with a timescale of less than 10 days [10-13]. The AEW is triggered by convective heating in the central and eastern Africa [12-16] and thereafter propagates westward to interact with convective systems $[17,18]$. The interaction between AEWs and convection results in a modulating effect on rain-producing systems (e.g., squall lines and precipitating cloud clusters) over West Africa [19-21] and is associated with more than $40 \%$ of Mesoscale Convective Systems (MCSs) [10]. These MCSs are well organized systems of individual thunderstorm cell which produces intense precipitation and contributes up to $80 \%$ of the annual regional rainfall over the Sahel [22-26].

All these components of the WAM discussed exhibit interannual and interseasonal variability patterns. Moreover, the WAM has been found to have relationship with the observed El Nino and La Nina events otherwise called the

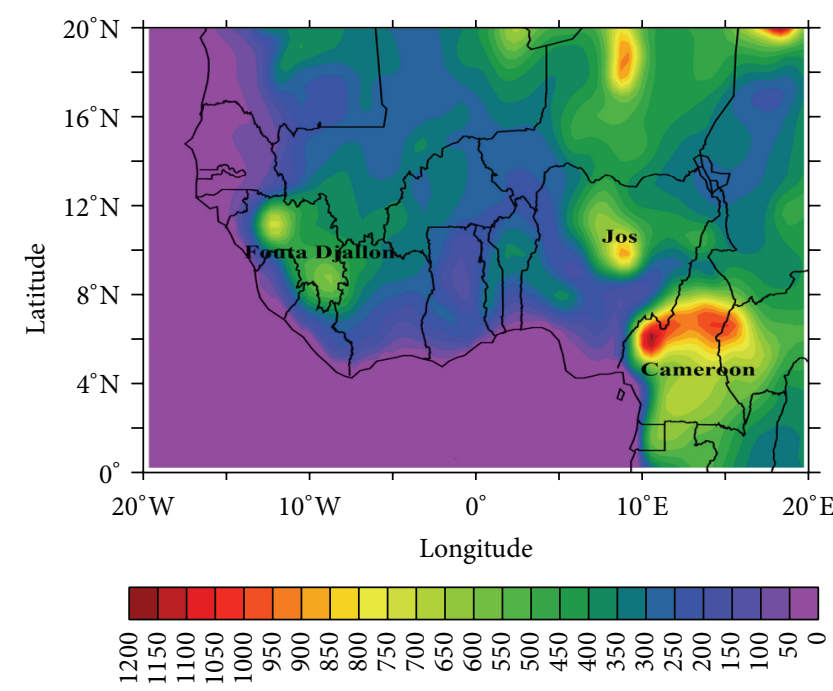

(m)

FIGURE 2: The topography as seen by the model in the study domain with resolution of $50 \mathrm{~km}$.

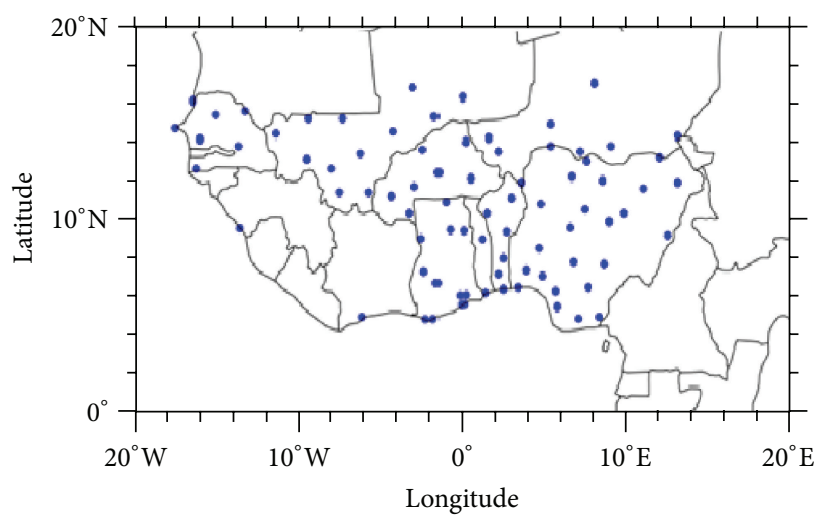

Figure 3: Spatial distribution of the Eighty-One (81) ground observation precipitation data sites used.

El Nino Southern Oscillation, an unusual warming phenomenon peculiar to the eastern and central part of the tropical Pacific Ocean. Critical study on this relationship has been explored with the conclusion that there exist periods of strong and weak correlations between WAM and ENSO [27]. The authors presented a significant negative impact of positive (warm) ENSO phases on the WAM precipitation after the 1970s. Also, recent study specified the role of the main global SST modes in driving the multidecadal variability of the WAM precipitation which is a major cause of the ENSO event [28].

Predominantly, influence of anthropogenic activities on climate is becoming ever so apparent, thereby causing changes in the WAM. However, assessing these impacts on regionally important sectors has become a major concern, especially for policy makers who develop action plans to mitigate and adapt to the impacts of future climate change. 


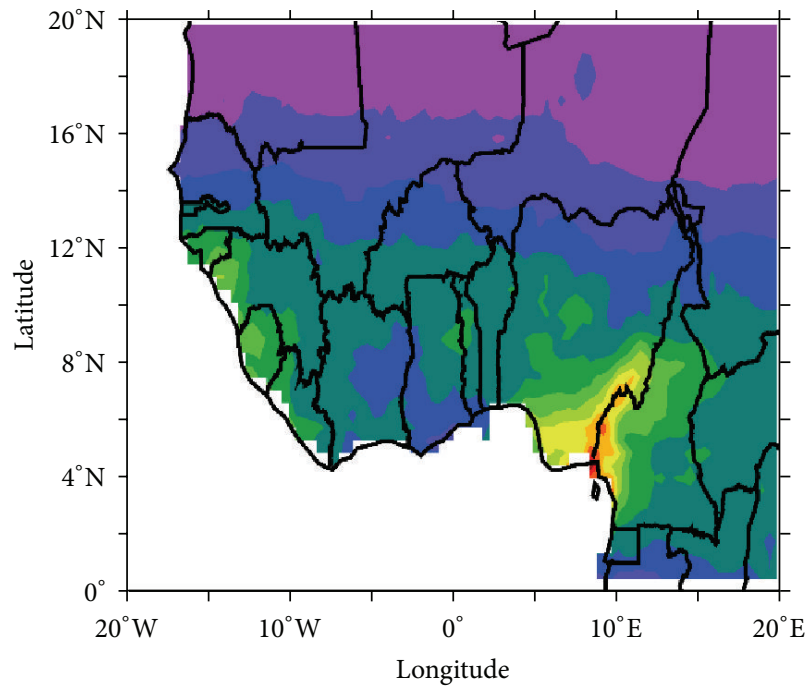

(a)

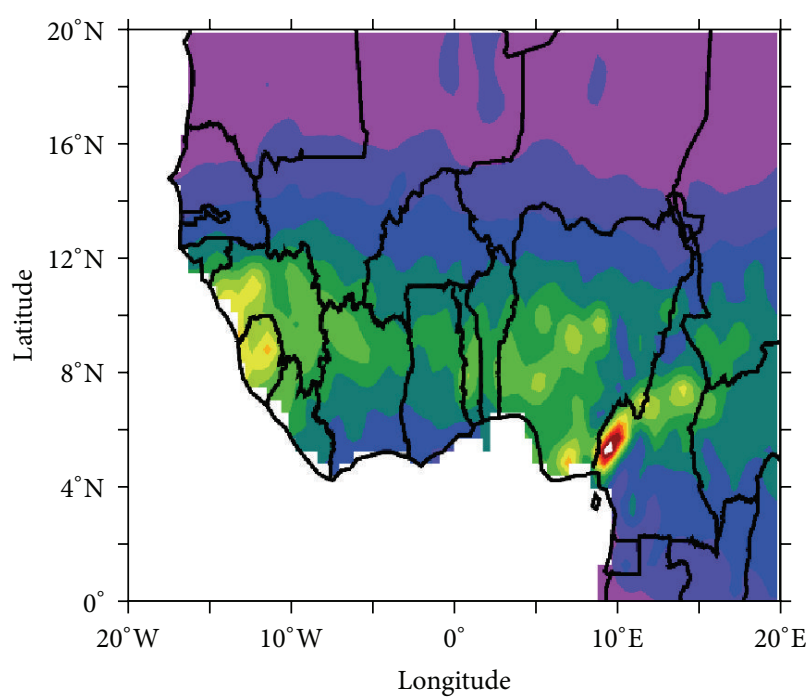

(c)

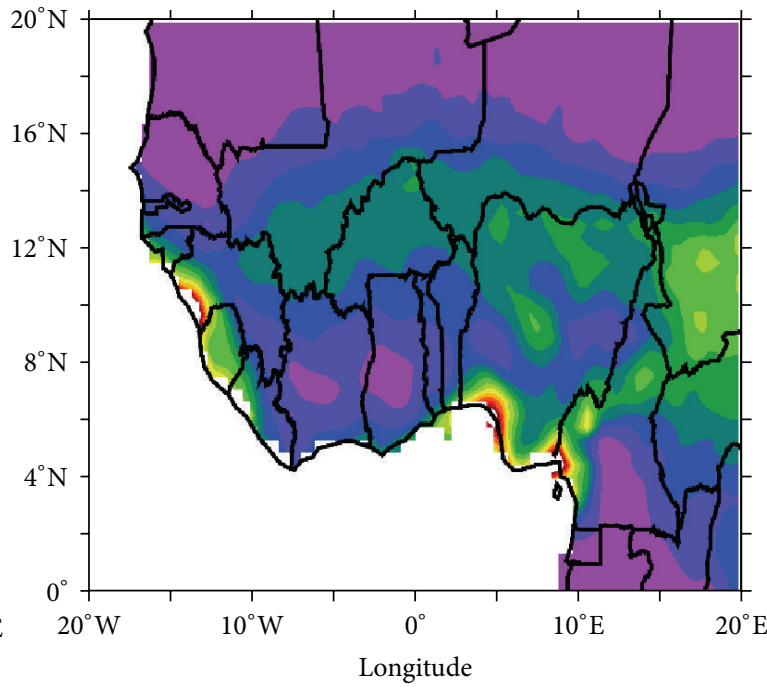

(b)

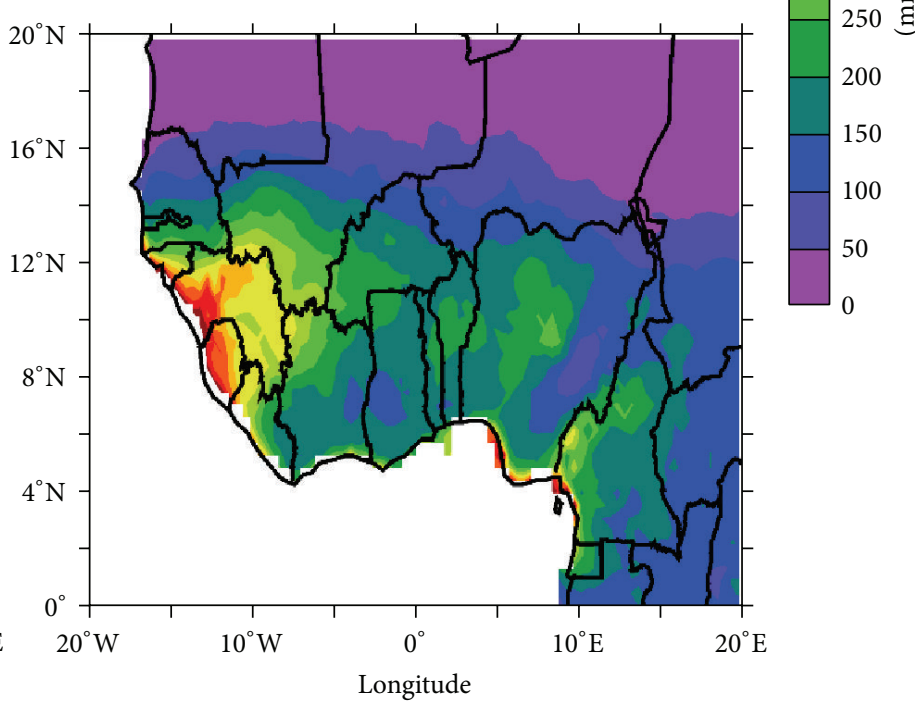

(d)

FIGURE 4: Spatial pattern of mean monthly JJAS precipitation (mm/month) for (a) TRMM, (b) CCLM, (c) RCA, and (d) REMO from 1998 to 2008 .

TABLE 1: Detailed output of the statistical analysis of the satellite and the CORDEX RCMS.

\begin{tabular}{|c|c|c|c|c|c|c|c|c|c|c|c|}
\hline & \multicolumn{4}{|c|}{ Guinean Coast } & \multirow{2}{*}{ Remarks } & & \multicolumn{4}{|c|}{ Savannah } & \multirow{2}{*}{ Remarks } \\
\hline & $\mathrm{MB}$ & MGE & RMSE & $r$ & & & $\mathrm{MB}$ & MGE & RMSE & $r$ & \\
\hline TRMM & -13.02 & 13.02 & 16.18 & 0.99 & Most suitable & TRMM & -35.29 & 35.29 & 35.89 & 0.94 & Most suitable \\
\hline CCLM & -40.99 & 49.20 & 52.79 & 0.97 & Most suitable & CCLM & -88.73 & 88.73 & 110.49 & -0.60 & Not suitable \\
\hline RCA & -20.39 & 29.94 & 35.01 & 0.66 & Suitable & RCA & -10.44 & 25.20 & 28.72 & 0.93 & Most suitable \\
\hline \multirow[t]{3}{*}{ REMO } & -26.20 & 37.33 & 39.42 & 0.94 & Most suitable & REMO & 8.83 & 51.02 & 51.98 & 0.11 & Not suitable \\
\hline & & \multicolumn{2}{|c|}{ Sahel } & & \multirow{2}{*}{ Remarks } & & \multicolumn{4}{|c|}{ West Africa } & \\
\hline & $\mathrm{MB}$ & MGE & RMSE & $r$ & & & MB & MGE & RMSE & $r$ & \\
\hline TRMM & 2.36 & 2.47 & 3.25 & 1.00 & Most suitable & TRMM & -8.39 & 8.39 & 9.19 & 0.90 & Most suitable \\
\hline CCLM & -3.87 & 33.72 & 35.78 & 0.62 & Most suitable & CCLM & -30.27 & 37.11 & 48.21 & -0.96 & Not suitable \\
\hline RCA & -16.17 & 26.23 & 31.36 & 0.94 & Most suitable & RCA & -15.30 & 21.24 & 26.27 & 0.30 & Not suitable \\
\hline REMO & 33.63 & 33.63 & 38.86 & 0.90 & Most suitable & REMO & 11.40 & 25.70 & 28.55 & -0.10 & Not suitable \\
\hline
\end{tabular}




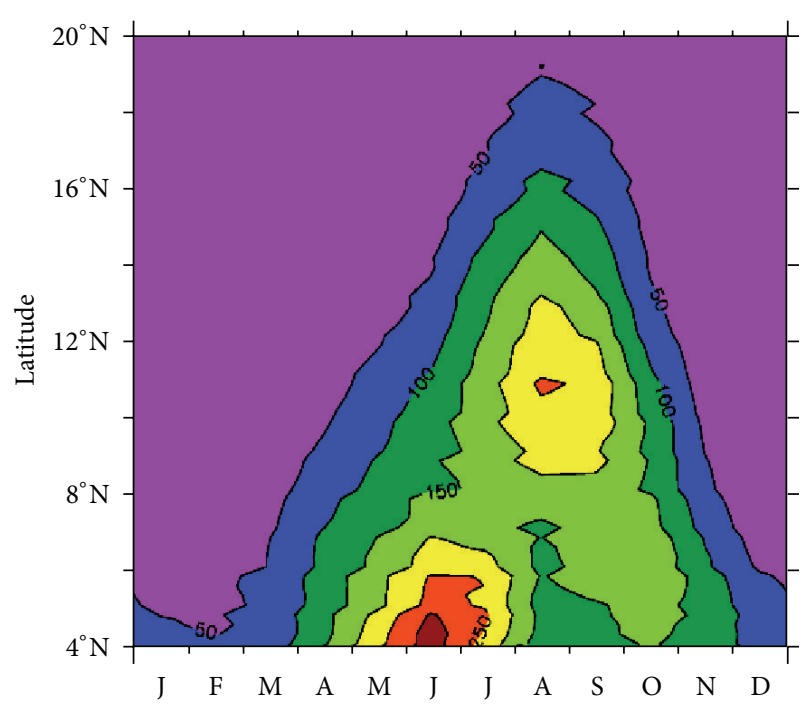

(a)

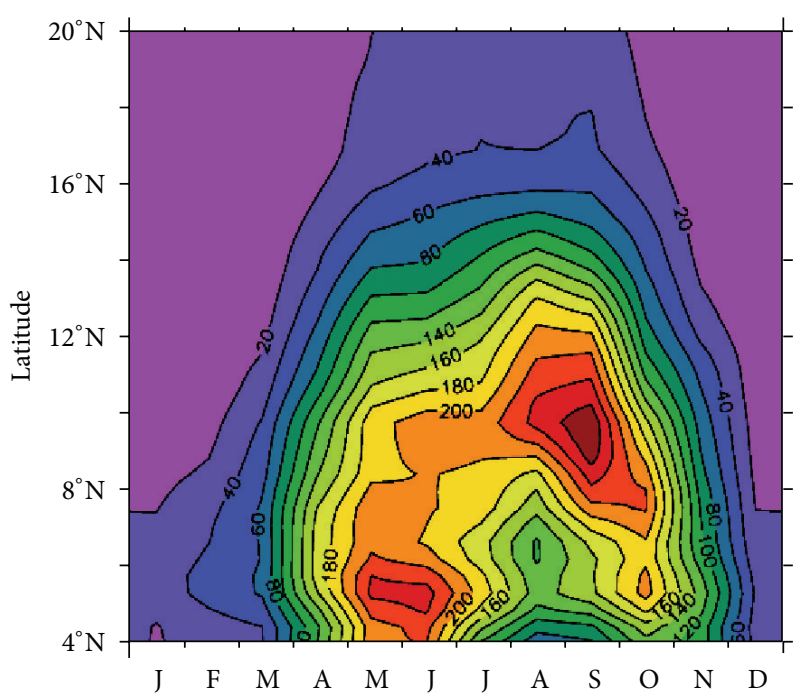

(c)



(b)

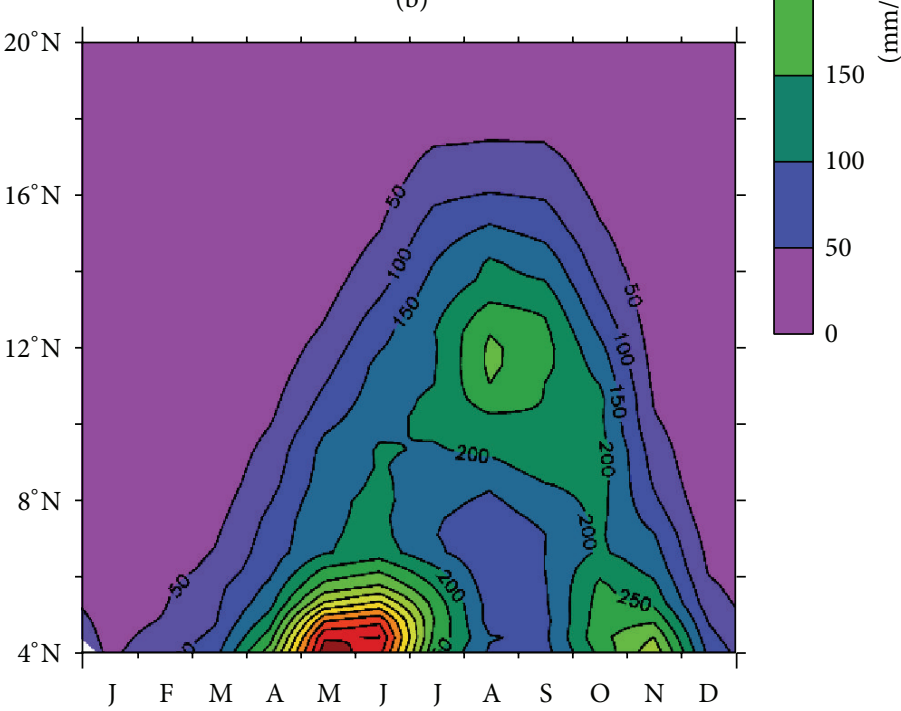

(d)

FIGURE 5: Time-latitude cross section of mean monthly rainfall (mm/month) for (a) TRMM, (b) CCLM, (c) RCA, and (d) REMO from 1998 to 2008 averaged over longitude $10 \mathrm{~W}$ to $10 \mathrm{E}$.

Evaluation of climate model is a fundamental step in estimating the uncertainty in future climate projections [29-31]. Policy makers, among the key users of climate information, rely on the projections of climate change impacts in their decision making. Because of the crucial role of climate models in this process, it is essential to characterize their strengths, weaknesses, and uncertainties. The primary tool for projecting climate is the Atmosphere-Ocean General Circulation Models (AOGCMs) which simulate climate changes under a range of future greenhouse gas emission scenarios and are typically run at horizontal resolution of $100-250 \mathrm{~km}$ owing to their massive computational and data storage requirements. However, these models have shown poor performance in simulating the main features responsible for triggering and maintaining the West African Monsoon (WAM) rainfall [32, 33]; hence for a detailed typical impact assessment, high spatial resolution models are required. Downscaling procedures have been developed and applied to derive regional to local-scale information from coarse resolution GCMs. Two downscaling techniques are used to produce regional climate information. Statistical downscaling used empirical relationships between large-scale atmospheric variables and local climate variables and has demonstrated the potential to produce useful and applicable information, though the application of statistical downscaling methods is hampered by the lack or dearth of long-enough observational data required at point or station scale to train and validate the statistical model. An alternative but computationally intensive approach that does not suffer from this restraint and captures mesoscale nonlinear effects is dynamical downscaling using high-resolution global models with variable spatial resolution [34]. However, the downscaling techniques suffer 


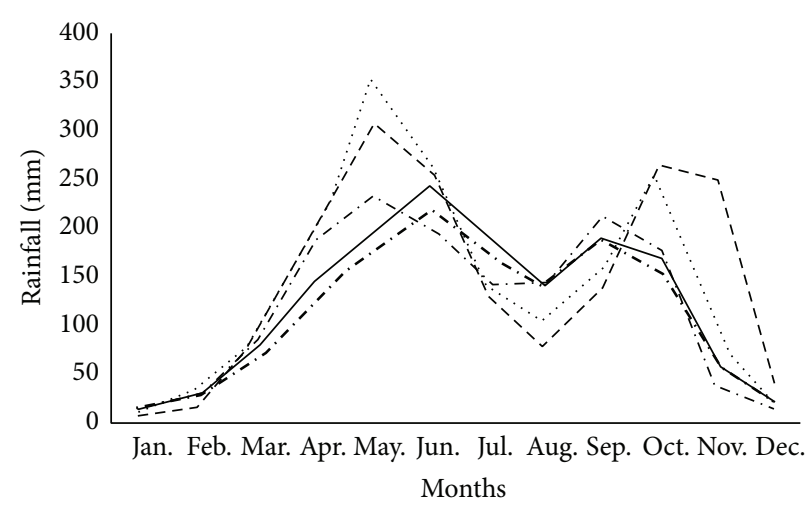

(a) Guinea Coast

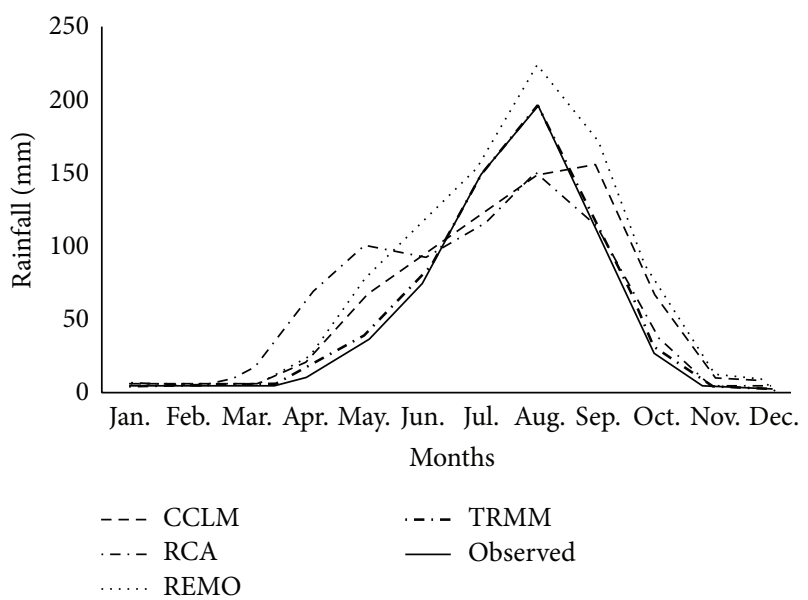

(c) Sahel

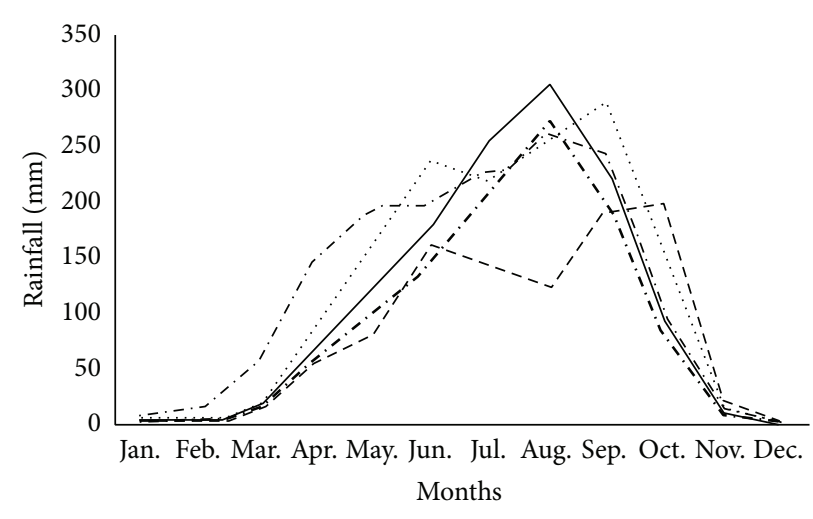

(b) Savannah

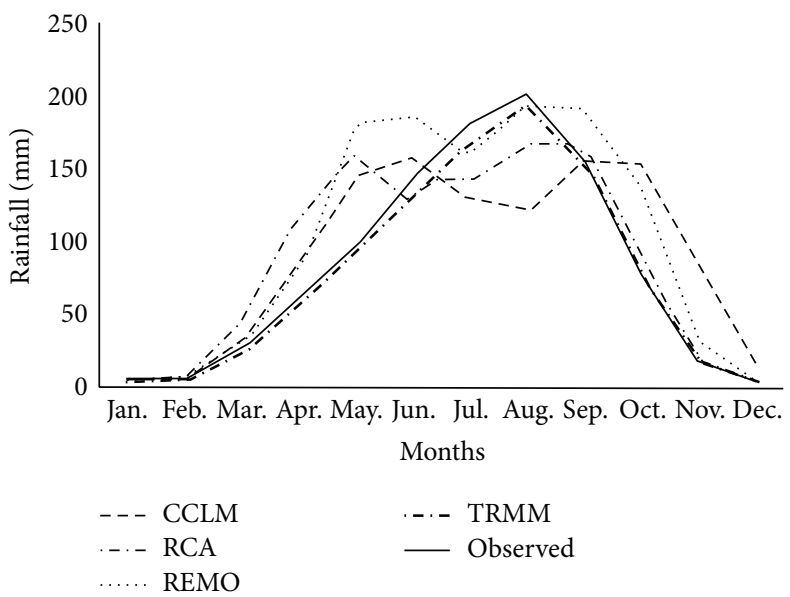

(d) Whole West Africa domain

FiguRE 6: Inter-seasonal variation of mean monthly precipitation (mm) over (a) Guinea Coast, (b) Savannah, (c) Sahel, and (d) for the whole West Africa domain.

from uncertainties inherited from the driving GCMs and from those associated with their internal workings. In view of this, several RCMs have already been tested over West Africa in previous studies [33, 35-39] for different purposes. Most of these studies focused on their skill in representing the annual or seasonal cycle of critical meteorological variables (rainfall, temperature, humidity, cloudiness, etc.). Reference [39] assessed the ability of the Regional Climate Model (RegCM3) to reproduce the seasonal temperature and precipitation cycle during the period of 1981-2000 over West Africa with two sets of boundaries conditions, reanalysis data, and ECHAM5 output. To systematically explore uncertainties associated with dynamical downscaling, coordinated Regional Climate Model (RCM) simulations are necessary. Such coordinated efforts are available in other regions, such as Europe [40], North America [41], and South America [42]. In Africa, the Coordinate Regional Climate Downscaling Experiment (CORDEX) is the first effort that focuses on the whole of Africa and furthermore treats it as a priority domain [43]. It consists of two phases: in the first phase downscaling centers are asked to downscale a reference/verification period using ERA-Interim reanalysis dataset from the European Centre for Medium-Range Weather Forecasts (ECMWF) [44], and in the second phase, data from the Coupled Model InterComparison Project phase 5 (CMIP5) GCMs from the period 1951-2100 is used. The extent to which CORDEX RCMs can adequately capture the important climate features and simulate key variables such as precipitation in Africa is not yet fully understood. However, this is an essential prerequisite as climate information obtained from the high-resolution CORDEX data will be used for climate change adaptation strategies and other applications. Hence, this paper therefore objectively evaluates the ability of CORDEX reference runs to simulate key climate variables, particularly precipitation, as an essential first step prior to assessing downscaled climate change scenario results over Africa. References [45, 46] used CORDEX simulation over Africa and demonstrated that the models simulate the mean seasonal and annual cycle adequately, although there are spatial biases amongst the model ensembles. Their results show that the multimodel average generally outperforms any individual simulation and that the RCMs significantly improve the precipitation climate compared to the driving ERA-Interim. Reference [47] analyzed the CRCM5 and found it to adequately capture the seasonal precipitation climatology over much of Africa and the annual cycle over southeastern Africa east of $20^{\circ} \mathrm{E}$. Slight 


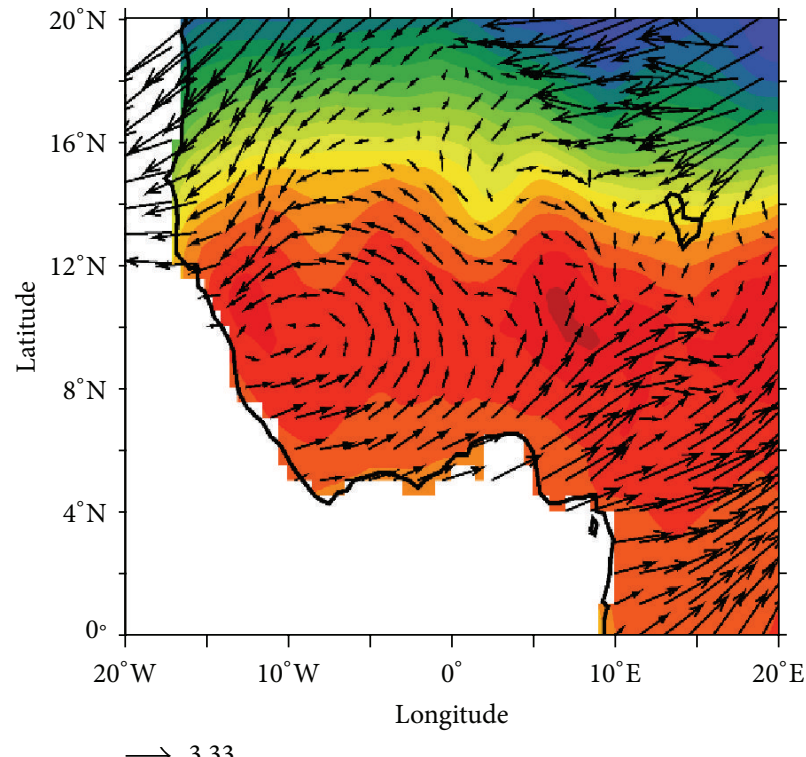

(a)

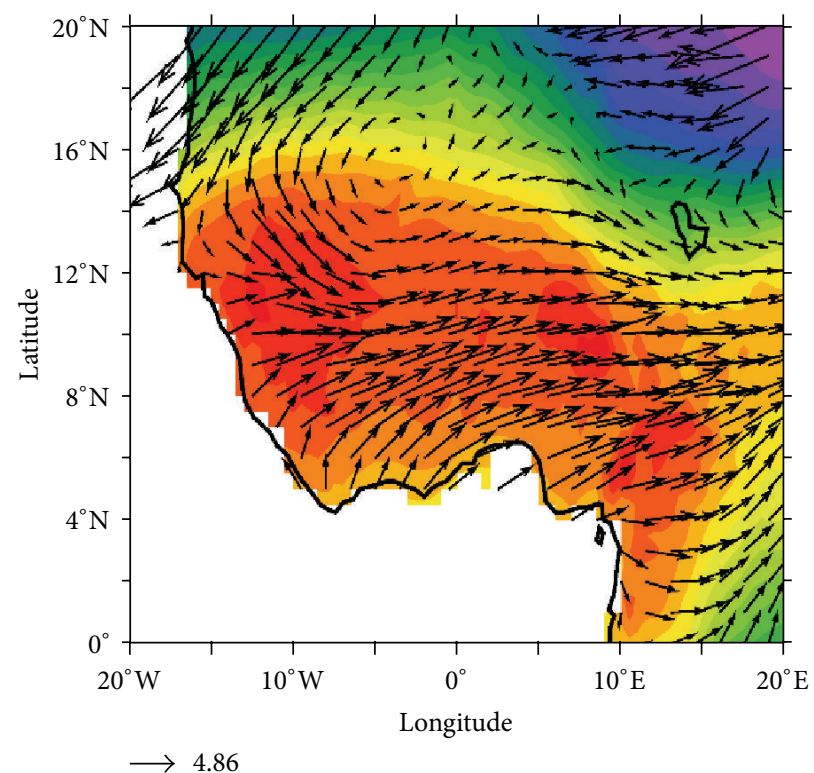

(c)

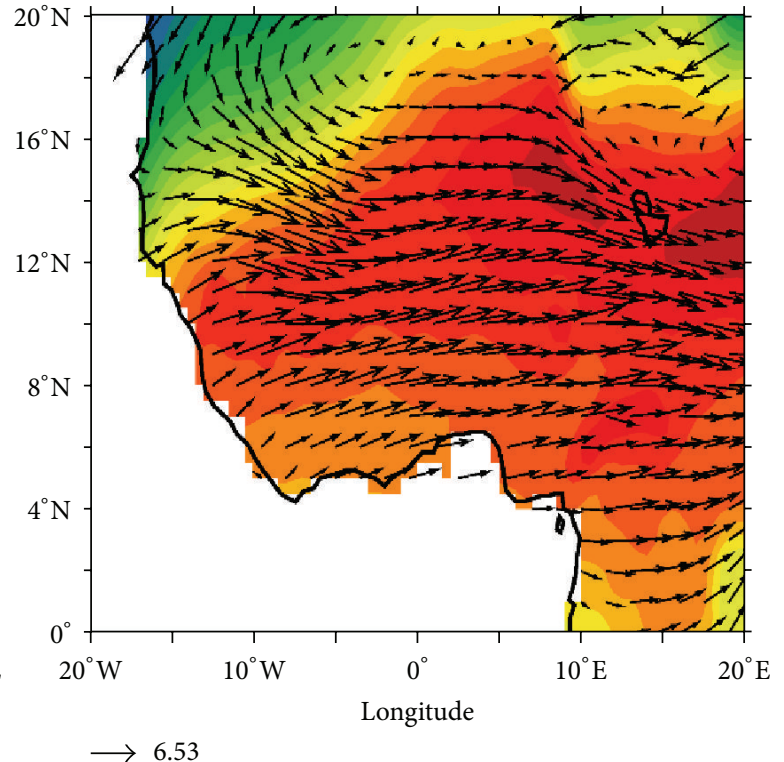

(b)

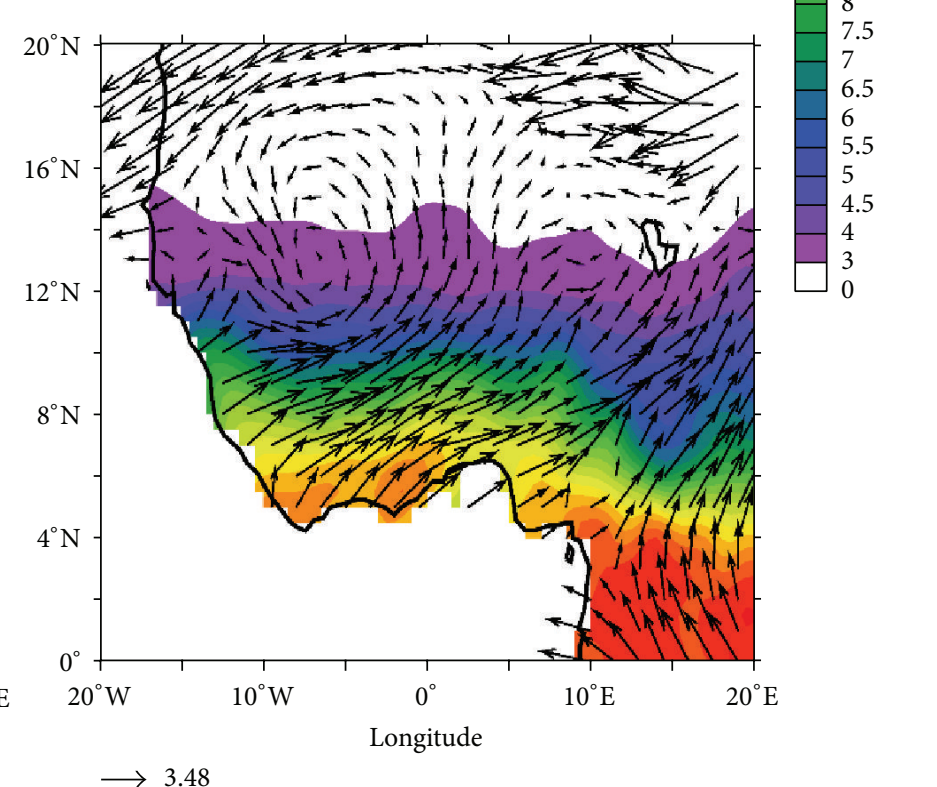

(d)

FIGURE 7: Spatial pattern of mean monthly JJAS $850 \mathrm{mb}$ specific humidity (g/kg) and wind field (m/s) for (a) ERA-Interim, (b) CCLM, (c) RCA, and (d) REMO from 1998 to 2008.

biases were found in simulating the diurnal precipitation cycle. In West Africa, [48] assesses the capability of CORDEX simulation to simulate climatology and annual cycle of precipitation and temperature and found that the RCMs show acceptable performance in simulating the spatial distribution and variability of the main precipitation and temperature features. A detailed statistical approach was further applied in this paper to evaluate rainfall simulation by three CORDEX RCMs over West Africa during the summer monsoon of June-September.

\section{Study Area}

The study area of this research is West Africa. The region as shown in Figure 1 broadly lies between longitudes $20^{\circ} \mathrm{W}$ and $20^{\circ} \mathrm{E}$ and latitudes $0^{\circ}$ and $20^{\circ} \mathrm{N}$. Geographically, the gulf of guinea is the southern boundary, while to the north it is the northern boundary of Mauritania, Mali, and Niger. Its eastern and western limits are, respectively, to Mount Cameroun and Atlantic Ocean. West Africa includes 16 countries politically: Nigeria, Cape Verde, Gambia, Benin, Ghana, Guinea-Conakry, Guinea-Bissau, Ivory Coast, Liberia, Mali, Mauritania, Niger, Senegal, Sierra Leone, Burkina Faso, and 


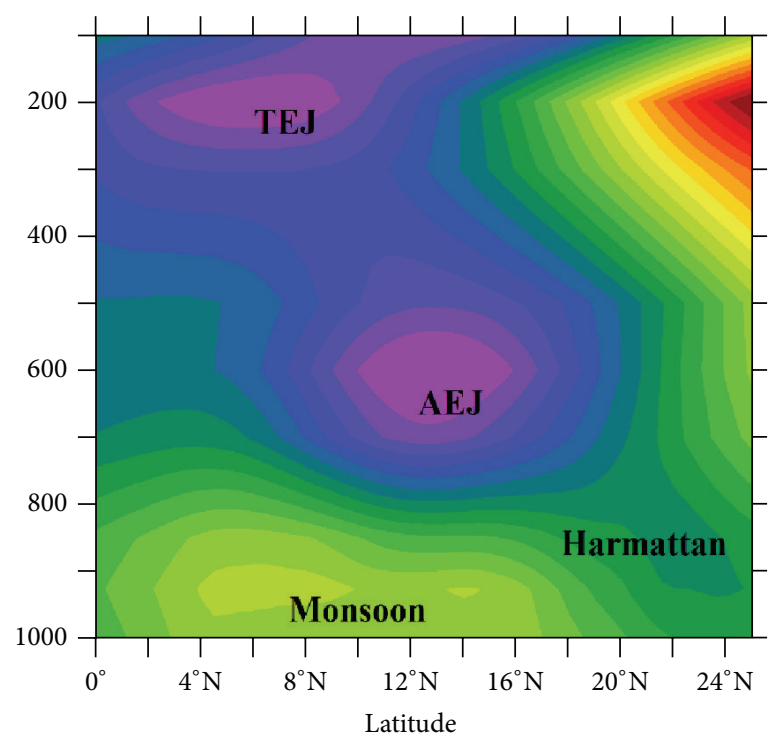

(a)

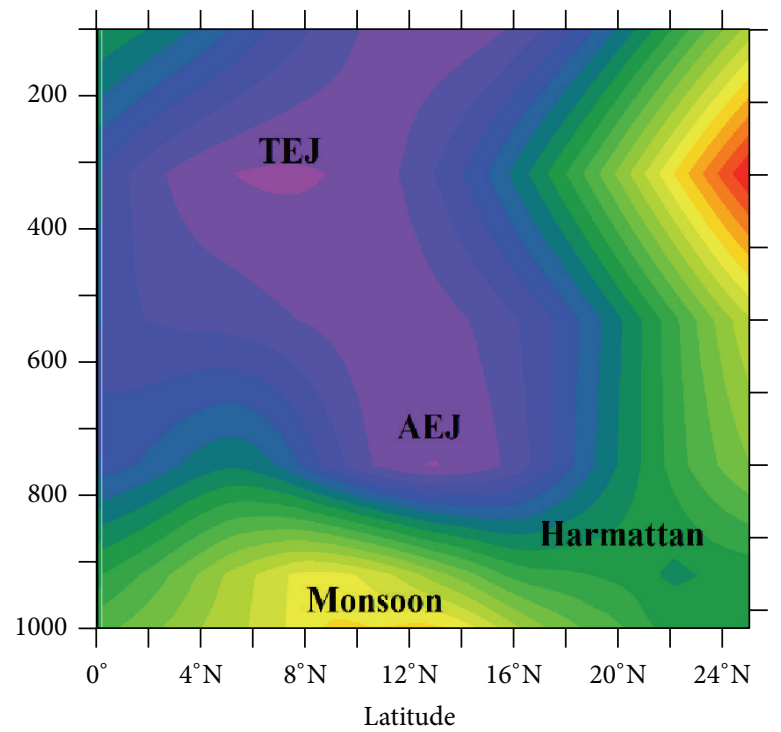

(c)

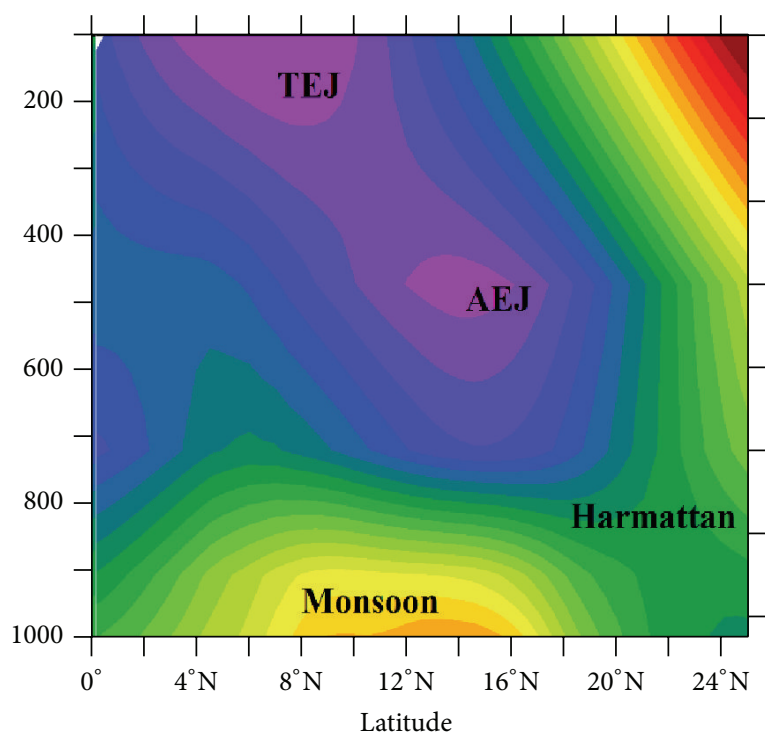

(b)

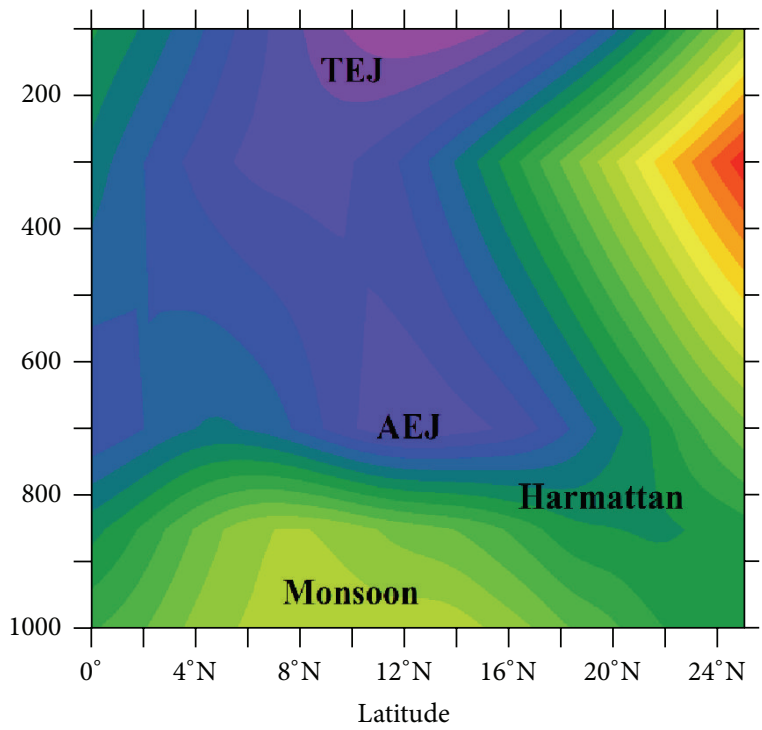

(d)

FIGURE 8: The vertical cross section of the zonal wind over West Africa from 1990 to 2008 for (a) ERA-Interim, (b) CCLM, (c) RCA, and (d) REMO during JJAS.

Togo, all occupying an area of approximately 5 million $\mathrm{km}^{2}$. However, following $[49,50]$ the West Africa domain is divided into three climatic zones as shown in Figure 1: Guinea Coast $\left(4^{\circ}-8^{\circ} \mathrm{N}\right)$, Savannah $\left(8^{\circ}-11^{\circ} \mathrm{N}\right)$, and Sahel (11$\left.16^{\circ} \mathrm{N}\right)$. The Guinea Coast represents the southern boundary to the Atlantic Ocean which is characterized by subhumid climate with an average annual rainfall between $1250 \mathrm{~mm}$ and $1500 \mathrm{~mm}$. The number of growing days periods (GDP) varies between 180 and 270 days. The Savannah zone is a semiarid zone with an average annual rainfall between $750 \mathrm{~mm}$ and $1250 \mathrm{~mm}$. However, this zone is affected by little dry season during the monsoon jump. The Sahel zone covers the northern boundary of Mauritania, Mali, and Niger characterized with a single rainfall peak but short rainy season (JuneSeptember) with a mean GDP and annual rainfall of about 90 days and $750 \mathrm{~mm}$, respectively. The variability in climate of West Africa is also greatly influenced by topography and some of the most important plateaus are Fouta Djallon, Jos Plateau, and Cameroon Highland (see Figure 2).

\section{Data and Methodology}

An ensemble of three RCMs participating in the CORDEXAfrica program is analyzed and intercompared in this study. The RCMs are integrated over the whole Africa domain continuously for the entire 20-year period from January 1989 through December 2008 at a spatial resolution of 


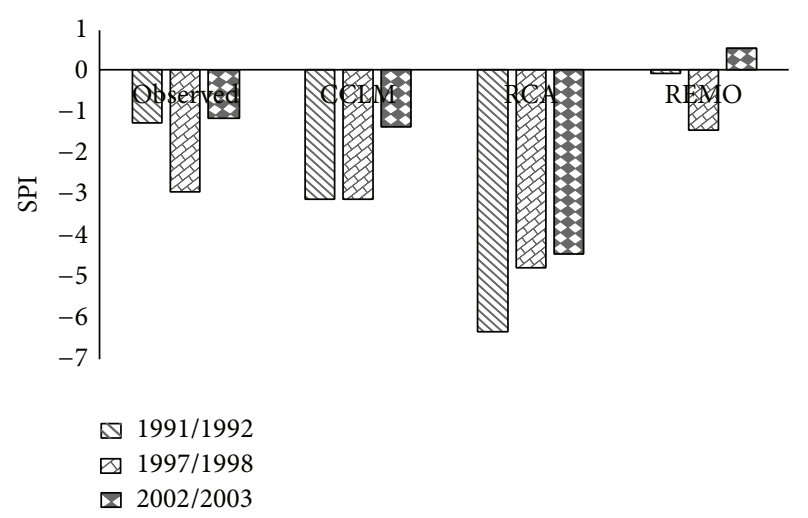

(a)

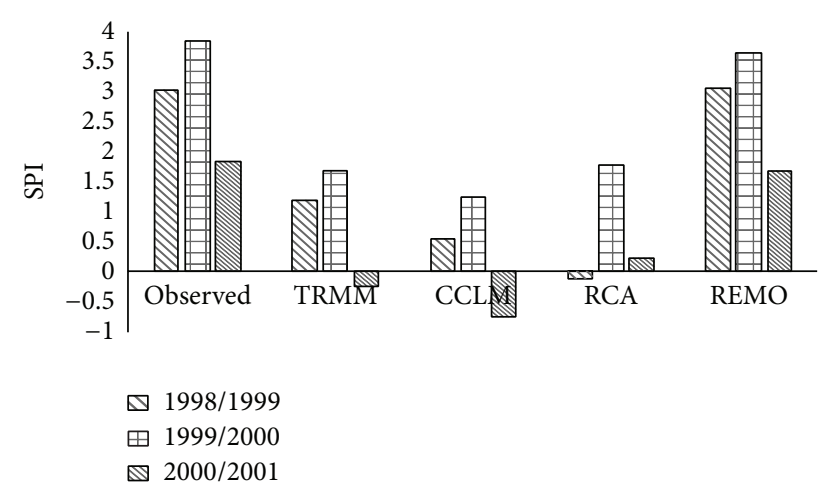

(b)

FIGURE 9: Standardized Precipitation Index for JJA associated with (a) El Nino events (using data for 1991/1992, 1997/1998, and 2002/2003) and (b) La Nina events (using data for 1998/1999, 1999/2000, and 2000/2001) as simulated by CORDEX RCMs, compared against the ground observation data and TRMM observation (TRMM excluded for El Nino because of data availability).

$50 \mathrm{~km}\left(\sim 0.44^{\circ}\right)$, employing the ERA-Interim reanalysis [44] at the lateral boundaries and for initialization. The RCMs data is from Climate Limited-Area Modeling (CLM) Community (CCLM4.8), Swedish Meteorological and Hydrological Institute, Sweden (SMHI-RCA35), and Max Plank Institute, Germany (MPI-REMO); all the RCMs participated in the CORDEX-Africa experiment. The simulations are evaluated over the West African domain of Figure 1, which exhibits some localized highlands around Cameroon (Cameroon Mountains), Central Nigeria (Jos Plateau), and Guinea (Guinea Highlands); see Figure 2. All the simulation datasets were obtained from the Climate Systems Analysis Group (CSAG) of the University of Cape Town, Cape Town, South Africa. Also, in a way to compare and validate the RCMs outputs, the study used precipitation data from ground observing station and satellite (TRMM). The ground observation data was collected over 81 meteorological stations in West Africa for the period of 1990-2008 (see Figure 3 for the spatial distributions) while the TRMM dataset was obtained from the Tropical Rainfall Measuring Mission (TRMM, 3B42 version $6[51,52])$ at $0.25^{\circ} * 0.25^{\circ}$ spatial resolutions from 1998 to 2008 . Furthermore, in a way to assess the dynamics of the RCMs pressure level data for wind and specific humidity was used. These data were retrieved from ERA-Interim reanalysis, a product from European Centre for MediumRange Weather Forecast (ECMWF) at $0.5^{\circ} * 0.5^{\circ}$ resolution from 1998 to 2008. It is worth mentioning that, for this analysis, the pressure level wind field required to assess the position and strength of the African Easterly Jet (AEJ) is absent in CORDEX output; in view of this pressure level wind data from Ensemble-AMMA project was used to assess the wind profile pattern. All the datasets are subjected to quality control and regridded to the same spatial resolution of $\sim 0.44^{\circ}$.

In a way to evaluate the performance of the dataset (Satellite and CORDEX RCMs) quantitatively relative to the ground observation data, a wide range of evaluation statistics are available to assess model performance [53-55]. There is, however, no single statistic that encapsulates all aspects of interest. For this reason it is useful to consider several performance statistics and also to understand the sort of information or insight they might provide. The following statistical methods were therefore used to assess the best satellite, gridded and RCMs dataset over the study area: mean bias (MB), mean gross error (MGE), root mean square error (RMSE), and correlation coefficient $(r)$. Also the standardized precipitation index, a tool which was developed primarily to monitor wet and dry years, was computed over West Africa domain for all the El Nino and La Nina years using the longterm mean, yearly mean, and the standard deviation of the precipitation data.

Because of the limited temporal resolution of TRMM data, some of the analysis will be limited to 1998-2008.

\section{Results and Discussion}

Before evaluating the RCMs ability to capture the interseasonal variability over West Africa, the degree to which the model captures the spatial pattern must be examined. The spatial pattern of mean monthly JJAS precipitation from 1998 to 2008 for the CORDEX RCMs was examined and compared with TRMM observation in Figure 4. In TRMM precipitation, the zone of highest/heaviest rainfall is observed to be around the coastal part extending from Liberia (south-west) towards the south eastern part of West Africa while north of latitude $10^{\circ}$ is having moderate to low rainfall. This observed region of low and high rainfall is consistent in all the three CORDEX RCMs but the amount of rainfall varies from one model to another. These observed results are in mutual agreement with the work of $[39,45,48]$. An interesting feature observed was that the zone of heaviest rainfall coincides with localized highlands in Guinea Coast, Cameroon Mountains, and Jos Plateau in Nigeria.

The time-latitude cross section of monthly mean rainfall from latitudes $4^{\circ}$ to $20^{\circ} \mathrm{N}$, averaged between longitudes $10^{\circ} \mathrm{W}$ and $10^{\circ} \mathrm{E}$ for (a) TRMM, (b) CCLM, (c) RCA, and (d) REMO from 1998 to 2008, is shown in Figure 5. The TRMM data shows an onset period between late March and June, which sees a gradual extension of the rain belt from coast to about $8^{\circ} \mathrm{N}$. A break was observed known as the monsoon jump [48, $56,57]$ which occurs in the rain band between June and July 


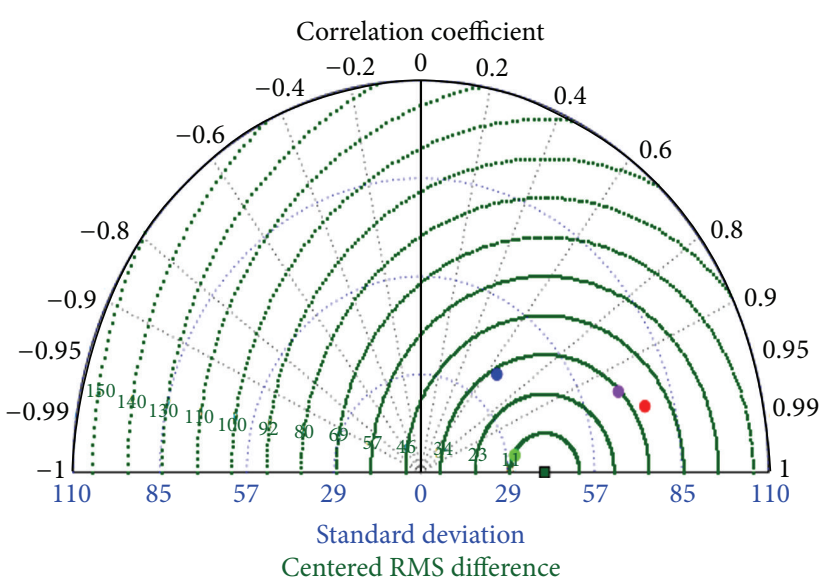

(a) Guinea Coast

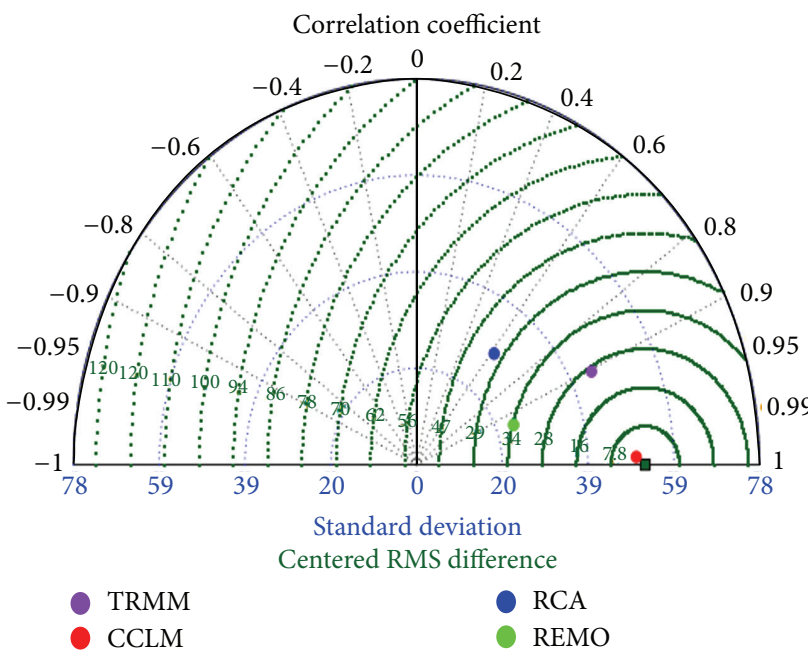

(c) Sahel

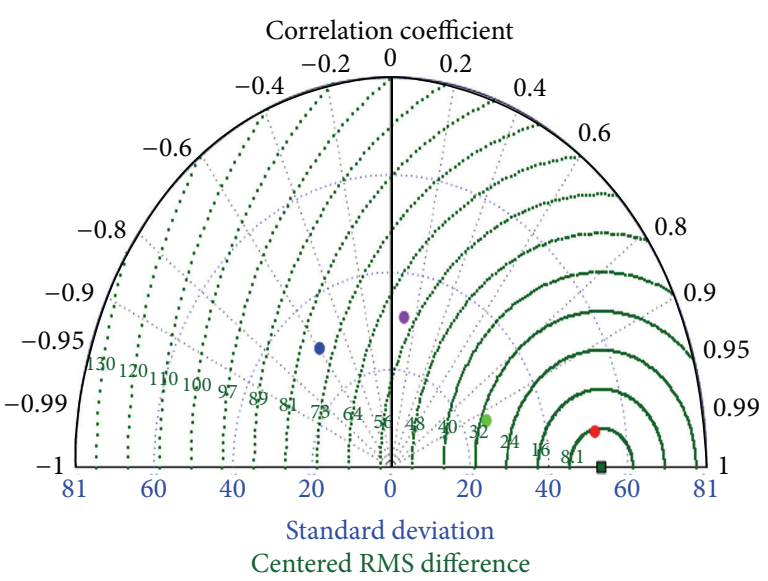

(b) Savannah

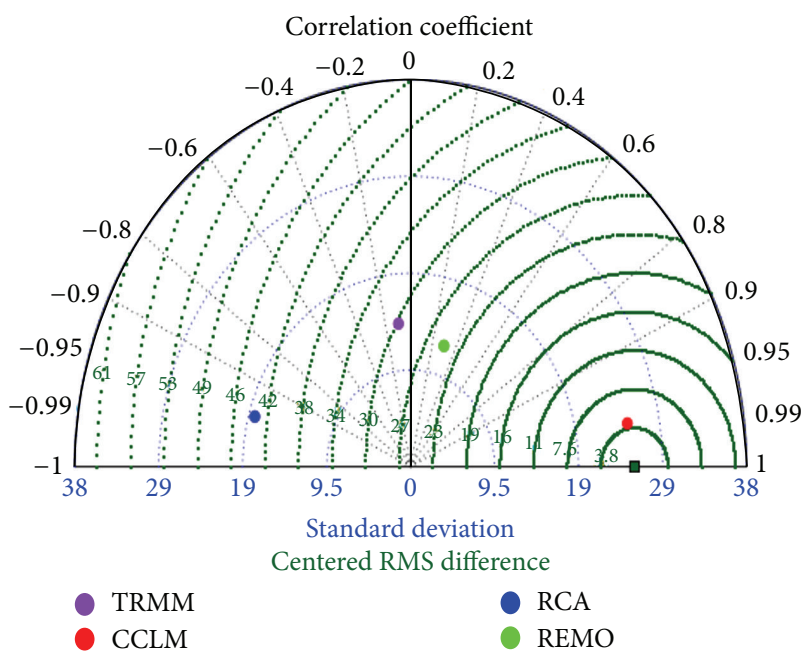

(d) The whole West Africa domain

FIGURE 10: Taylors diagram per subregion for (a) Guinea Coast, (b) Savannah, (c) Sahel, and (d) the whole West Africa domain during JJAS for the period of 1998-2008.

leading to the northward shift of the monsoon precipitation to about $10^{\circ} \mathrm{N}$ resulting in high rainfall amounts in the Sahel region of West Africa accompanied by abrupt cessation in precipitation intensities along the Guinean Coast. However a number of differences were observed with regard to the magnitude and spatial extent of these features. For instance, RCA fails to distinctively reproduce the monsoon jump while CCLM and RCA largely overestimated the pre- and the postmonsoon precipitation. The inability of the models to capture the observed features of the WAM may be as a result of their failure to adequately simulate the triggering mechanisms of the WAM precipitation, for example, African Easterly Jet (AEJ), Tropical Easterly Jet (TEJ), and African Easterly Waves as concluded in earlier studies [8, 37, 58]. Overall, the three distinct phases of the mean annual cycle of the West Africa Monsoon precipitation are generally well captured by REMO and poorly replicated by CCLM and RCA due to their under- and overestimation, respectively.

Furthermore, a detailed additional analysis of the annual cycle was carried out considering the area-averaged value of monthly rainfall using ground observation data from 81 stations across West Africa to validate the TRMM and RCM rainfall data as shown in Figure 6. This helps to better identify rainfall minima and maxima and thus to further gain insights into the capability of TRMM data and the RCMs to capture phases and amplitudes rainfall $(\mathrm{mm})$ in the specific homogenous zone in West Africa. Over the Guinea Coast (see Figure 6(a)) ground observation data exhibits two peaks of rainfall, a primary maximum in June, a secondary one in September, and a relative mid-summer low (minimum) in August as the monsoon rainband seasonally migrates in the north-south direction. However, observed were some slight differences in the intensities among the TRMM and RCMs predominantly during the peaks of rainfall; it is worth mentioning that the RCMs replicate the observed pattern but overestimate rainfall amount. In the Savannah (see Figure 6(b)), the length of rainy season extends from May to September; however rainfall exhibits a unimodal pattern, having its peak in the month of August. All the models underestimated the rainfall amount during the summer 
month but captured the pattern except CCLM. Over the Sahel (see Figure 6(c)), the length of rainy season is less than four months between July and September with August having the highest rainfall amount; the TRMM data and RCMs capture the described pattern but underestimate the amount. Summarily, over the entire West Africa domain (see Figure 6(d)), July to September was observed to have the highest rainfall and this is consistent in the TRMM and the RCMs. It is worth saying that the CORDEX RCMs used capture the interseasonal variability of precipitation except for CCLM.

The performance of the model requires further examination into the dynamics of the monsoon, particularly to ascertain the role of the wind field in the rainfall distribution of West Africa. Hence analysis of the $850 \mathrm{mb}$ specific humidity and wind fields is carried out in Figure 7 in a way to assess the moisture transport and depth by West African Westerly Jet (WAMJ) $[6,7]$. In ERA-interim, observed was a narrow band of westerlies located at about $4^{\circ}$ and $8^{\circ} \mathrm{N}$; these westerlies coming from the Atlantic Ocean extend eastward as far as $20^{\circ} \mathrm{E}$ having maximum speed of $3.33 \mathrm{~m} / \mathrm{s}$ centered at approximately $12^{\circ} \mathrm{E}$ over the Cameroon Mountains. Weak westerlies $(1 \mathrm{~m} / \mathrm{s})$ over the continent extend northwards as far as $18^{\circ} \mathrm{N}$, overlain by easterlies over the Saharan region. Two peaks of easterlies are found embedded between latitudes $15^{\circ}$ and $20^{\circ} \mathrm{N}$. The first is located between $20^{\circ}$ and $10^{\circ} \mathrm{W}$ and has maximum value of about $5.7 \mathrm{~m} / \mathrm{s}$. The second is located between $10^{\circ}$ and $20^{\circ} \mathrm{E}$ and is comparable in magnitude to the first. Compared to ERA-Interim the RCMs simulated winds tend to be stronger and the westerly jet spans more latitudes; these westerlies extend zonally between $4^{\circ}$ and $12^{\circ} \mathrm{N}$ with local westerly maxima of $6 \mathrm{~m} / \mathrm{s}$ concentrated at approximately $12^{\circ} \mathrm{N}$. Also, the RCMs simulate the maximum westerly flow at $12^{\circ} \mathrm{E}$ but locate it farther north, along Lake Chad at $10^{\circ} \mathrm{N}$ with a dominance of cyclonic circulation over Mauritania in two of the models (RCA and REMO). This circulation can be attributed to a very large extent moisture convergence (owing to high specific humidity loading) which can be related to large deviation in precipitation simulated by two RCMs mentioned earlier. Furthermore, the models simulate monsoon that penetrates northward to about $16^{\circ} \mathrm{N}$, covering the lower half of the Sahel. The difference in the northward extent of the monsoon between ERA-Interim and RCMs may be due to the differences in the strength of the simulated westerlies as indicated earlier, in particular, the westerly jet. In fact, studies have shown that the low-level westerly jet is an important agent for transporting moisture from the eastern tropical Atlantic Ocean into continental West Africa during boreal summer [56-58].

Furthermore, the vertical cross section of the zonal wind over West Africa from 1998 to 2008 for (a) ERA-Interim, (b) CCLM, (c) RCA, and (d) REMO during West Africa Summer Monsoon months of JJAS is shown in Figure 8. In ERA-interim a stratified structure of the atmospheric circulation located the monsoon flow $\left(4-14^{\circ} \mathrm{N}\right)$ at low level, the African Easterly Jest (AEJ) at the midlevel at about 600$700 \mathrm{hPa}$ centered at about $12-15^{\circ} \mathrm{N}$ and the Tropical Easterly Jet at $200 \mathrm{hPa}$ and centered around $10-11^{\circ} \mathrm{N}$. The depth and northward extent of the monsoon flow and the associated westerlies were reasonably simulated by the RCMs, although the intensity was slightly underestimated. In addition the ITD front is well reproduced and the AEJ is well simulated around $700 \mathrm{hPa}$ by RCA and REMO but its strength is underestimated and the core is a bit shifted to the north. In the upper troposphere, two of the RCMs distinctly reproduce the strength, location, and depth of the TEJ. However, the shift of jet core and the overestimation of easterlies are related to an excessively strong surface temperature gradient over land as observed by $[8,39]$ and to a great extent have impacts on the West Africa precipitation amount and its variability.

Rainfall anomalies over West Africa during the summer month of 1991/1992, 1997/1998, and 2002/2003 associated with El Nino years (Figure 9(a)) and 1998/1999, 1999/2000, and 2000/2001 La Nina years (Figure 9(b)) using the ground observation data as the reference were further investigated. Negative anomalies were observed during the El Nino years which can imply dry conditions. It is worth saying that CCLM and RCA capture this extreme but overestimated the intensity to a very large extent while REMO only captures the El Nino events of 1997/1998. In contrast, positive anomalies prevailed during the La Nina years with REMO replicating almost perfectly the observed events. However, CCLM and RCA only capture this event during 1999/2000. These observed positive anomalies imply wetter than normal rainfall conditions over West Africa. The finding is similar to the work of the authors of [59-62] who reported separately in their works that ENSO tends to influence rainfall.

Taylor diagrams [63] were used to validate the models result against ground observation precipitation data in each subregion (Figures 10(a)-10(d)) using seasonal means of June-September (JJAS) for the period of 1998-2008.

The mean bias error, mean gross error, root mean square error (RMSE), Pearson's correlation coefficient, and standard deviation (SD) were used for the validation. To provide an overview of observational uncertainty, TRMM data is also compared to the ground observation data and plotted on the same diagram. The satellite data used (TRMM) was observed to be in good agreement with the observed data to about $90 \%$ owing to its high correlation values (greater than 0.90 ) and relatively low errors with standard deviation in the vicinity of the ground observation data. This makes the TRMM data most suitable in replicating precipitation pattern over the subregion and the entire West Africa domain as shown in Table 1. However, Table 1 further shows that all the RCMs perform well in Guinea Coast and Sahel owing to their high correlation values while in Savannah only RCA performs well. However, CCLM and REMO exhibit high RMSE, MB, and MGE compared with RCA in Guinea Coast and Sahel.

\section{Conclusion}

In this study, three CORDEX RCMs were analyzed for their ability to capture and characterize rainfall patterns over West Africa region during the monsoon season of June-September from 1998 to 2008. Results show that the observed region of low and high rainfall is consistent in all the three CORDEX RCMs but the amount of rainfall varies to some extent. 
Results further show that the three distinct phases of the mean annual cycle of the West Africa Monsoon precipitation are generally well captured by REMO and poorly replicated by CCLM and RCA. However, based on the interseasonal variation of precipitation over the subregions and the whole West Africa, the RCMs tend to underestimate rainfall amount during the summer month but captured the pattern except CCLM. Furthermore, analysis of $850 \mathrm{mb}$ specific humidity and wind field reveals that the RCMs simulated winds tend to be stronger, the westerly jet spanning more latitudes. Also observed was a dominance of cyclonic circulation over Mauritania in two of the models (RCA and REMO). This circulation was attributed to a very large extent to moisture convergence (owing to high specific humidity loading) which can be related to large deviation in precipitation simulated by two RCMs mentioned earlier. The RCMs capture the Monsoon layer, AEJ, and TEJ with little variations in position and intensity. The models were found to simulate the drier than average conditions observed during El Nino events and wetter than normal conditions observed during the La Nina event though the intensity was overestimated in most of the RCMs. In general, this study has demonstrated that the three CORDEX RCMs simulate West Africa rainfall fairly and can therefore be used for the assessment of West African Summer Monsoon and future climate projections.

\section{Conflict of Interests}

The authors declare that there is no conflict of interests regarding the publication of this paper.

\section{References}

[1] S. Janicot, G. Caniaux, F. Chauvin et al., "Intraseasonal variability of the West African monsoon," Atmospheric Science Letters, vol. 12, no. 1, pp. 58-66, 2011.

[2] B. Rodríguez-Fonseca, S. Janicot, E. Mohino et al., "Interannual and decadal SST-forced responses of the West African monsoon," Atmospheric Science Letters, vol. 12, no. 1, pp. 67-74, 2011.

[3] B. Fontaine, J. Garcia-Serrano, P. Roucou et al., "Impacts of warm and cold situations in the Mediterranean basins on the West African monsoon: observed connection patterns (19792006) and climate simulations," Climate Dynamics, vol. 35 , no. 1, pp. 95-114, 2010.

[4] P. J. Lamb, "Case studies of tropical Atlantic surface circulation patterns during recent sub-Saharan weather anomalies: 1967 and 1968," Monthly Weather Review, vol. 106, no. 4, pp. 482-491, 1978.

[5] M. L. Parry, O. F. Canziani, J. P. Palutikof, P. J. van der Linden, and C. E. Hanson, Eds., Climate Change 2007: Impacts, Adaptation and Vulnerability. Contribution of Working Group II to the Fourth Assessment Report of the Intergovernmental Panel on Climate Change, Cambridge University Press, Cambridge, UK, 2007.

[6] S. A. Grodsky, J. A. Carton, and S. Nigam, "Near surface westerly wind jet in the Atlantic ITCZ," Geophysical Research Letters, vol. 30, no. 19, 2003.

[7] B. Pu and K. H. Cook, "Role of the west African westerly jet in sahel rainfall variations," Journal of Climate, vol. 25, no. 8, pp. 2880-2896, 2012.
[8] K. H. Cook, "Generation of the African easterly jet and its role in determining West African precipitation," Journal of Climate, vol. 12, no. 5, pp. 1165-1184, 1999.

[9] C. D. Thorncroft and M. Blackburn, "Maintenance of the African easterly jet," Quarterly Journal of the Royal Meteorological Society, vol. 125, no. 555, pp. 763-786, 1999.

[10] T. N. Carlson, "Synoptic histories of three African disturbances that developed into Atlantic hurricanes," Monthly Weather Review, vol. 97, no. 3, pp. 256-276, 1969.

[11] R. W. Burpee, "The origin and structure of easterly waves in the lower troposphere of North Africa," Journal of the Atmospheric Sciences, vol. 29, no. 1, pp. 77-90, 1972.

[12] J. P. Duvel, "Convection over tropical Africa and the Atlantic Ocean during northern summer. Part II: modulation by easterly waves," Monthly Weather Review, vol. 118, no. 9, pp. 1855-1868, 1990.

[13] G. N. Kiladis, C. D. Thorncroft, and N. M. J. Hall, "Threedimensional structure and dynamics of African easterly waves. Part I: observations," Journal of the Atmospheric Sciences, vol. 63, no. 9, pp. 2212-2230, 2006.

[14] G. J. Berry and C. D. Thorncroft, "Case study of an intense African easterly wave," Monthly Weather Review, vol. 133, no. 4, pp. 752-766, 2005.

[15] A. Mekonnen, C. D. Thorncroft, and A. R. Aiyyer, "Analysis of convection and its association with African easterly waves," Journal of Climate, vol. 19, no. 20, pp. 5405-5421, 2006.

[16] J.-S. Hsieh and K. H. Cook, "On the instability of the African easterly jet and the generation of African waves: reversals of the potential vorticity gradient," Journal of the Atmospheric Sciences, vol. 65, no. 7, pp. 2130-2151, 2008.

[17] R. J. Cornforth, B. J. Hoskins, and C. D. Thorncroft, “The impact of moist processes on the African Easterly Jet-African Easterly Wave system," Quarterly Journal of the Royal Meteorological Society, vol. 135, no. 641, pp. 894-913, 2009.

[18] G. J. Berry and C. D. Thorncroft, "African easterly wave dynamics in a mesoscale numerical model: the upscale role of convection," Journal of the Atmospheric Sciences, vol. 69, no. 4, pp. 1267-1283, 2012.

[19] M. Fortune, "Properties of African squall lines inferred from time-lapse satellite imagery," Monthly Weather Review, vol. 108, no. 2, pp. 153-168, 1980.

[20] C. W. Landsea and W. M. Gray, "The strong association between Western Sahelian monsoon rainfall and intense Atlantic hurricanes," Journal of Climate, vol. 5, no. 5, pp. 435-453, 1992.

[21] A. Gaye, A. Viltard, and P. de Félice, "Squall lines and rainfall over Western Africa during summer 1986 and 87," Meteorology and Atmospheric Physics, vol. 90, no. 3-4, pp. 215-224, 2005.

[22] L. Le Barbé and T. Lebel, "Rainfall climatology of the HAPEXSahel region during the years 1950-1990," Journal of Hydrology, vol. 188-189, no. 1-4, pp. 43-73, 1997.

[23] N. D'Amato and T. Lebel, "On the characteristics of the rainfall events in the sahel with a view to the analysis of climatic variability," International Journal of Climatology, vol. 18, no. 9, pp. 955-974, 1998.

[24] H. Laurent, N. D'Amato, and T. Lebel, "How important is the contribution of the mesoscale convective complexes to the Sahelian rainfall?" Physics and Chemistry of the Earth, vol. 23, no. 5-6, pp. 629-633, 1998.

[25] J.-L. Redelsperger, A. Diongue, A. Diedhiou et al., "Multi-scale description of a Sahelian synoptic weather system representative of the West African monsoon," Quarterly Journal of the 
Royal Meteorological Society, vol. 128, no. 582, pp. 1229-1257, 2002.

[26] A. H. Fink, D. G. Vincent, and V. Ermert, "Rainfall types in the West African Sudanian zone during the summer monsoon 2002," Monthly Weather Review, vol. 134, no. 8, pp. 2143-2164, 2006.

[27] S. Janicot, S. Trzaska, and I. Poccard, "Summer Sahel-ENSO teleconnection and decadal time scale SST variations," Climate Dynamics, vol. 18, no. 3-4, pp. 303-320, 2001.

[28] E. Mohino, S. Janicot, and J. Bader, "Sahel rainfall and decadal to multi-decadal sea surface temperature variability," Climate Dynamics, vol. 37, no. 3, pp. 419-440, 2011.

[29] “Validation required," Nature, vol. 463, no. 7283, p. 849, 2010.

[30] J. Kim and J.-E. Lee, "A multi-year regional climate hindcast for the Western United States using the mesoscale atmospheric simulation model," Journal of Hydrometeorology, vol. 4, no. 5, pp. 878-890, 2003.

[31] S.-Y. Hong, N.-K. Moon, K.-S. S. Lim, and J.-W. Kim, "Future climate change scenarios over Korea using a multi-nested downscaling system: a pilot study," Asia-Pacific Journal of Atmospheric Sciences, vol. 46, no. 4, pp. 425-435, 2010.

[32] F. Hourdin, I. Musat, F. Guichard et al., "AMMA—-model intercomparison project," Bulletin of the American Meteorological Society, vol. 91, no. 1, pp. 95-104, 2010.

[33] M. B. Sylla, E. Coppola, L. Mariotti et al., "Multiyear simulation of the African climate using a regional climate model (RegCM3) with the high resolution ERA-interim reanalysis," Climate Dynamics, vol. 35, no. 1, pp. 231-247, 2010.

[34] F. Giorgi and L. O. Mearns, "Introduction to special section: regional climate modelling revisited," Journal of Geophysical Research, vol. 104, no. 6, pp. 6335-6352, 1999.

[35] E. A. Afiesimama, J. S. Pal, B. J. Abiodun, W. J. Gutowski Jr., and A. Adedoyin, "Simulation of West African monsoon using the RegCM3. Part I: model validation and interannual variability," Theoretical and Applied Climatology, vol. 86, no. 1-4, pp. 23-37, 2006.

[36] A. K. Foamouhoue and E. Buscarlet, "Simulation du climat de l'Afrique de l'ouest a l'aide d'un modele climatique régional: validation sur la période 1961-1990," La Météorologie, vol. 52, pp. 28-37, 2006.

[37] H. Paeth, N. M. J. Hall, M. A. Gaertner et al., "Progress in regional downscaling of west African precipitation," Atmospheric Science Letters, vol. 12, no. 1, pp. 75-82, 2011.

[38] E. Vanvyve, N. Hall, C. Messager, S. Leroux, and J.-P. van Ypersele, "Internal variability in a regional climate model over West Africa," Climate Dynamics, vol. 30, no. 2-3, pp. 191-202, 2008.

[39] M. B. Sylla, A. T. Gaye, J. S. Pal, G. S. Jenkins, and X. Q. Bi, "High-resolution simulations of West African climate using regional climate model (RegCM3) with different lateral boundary conditions," Theoretical and Applied Climatology, vol. 98, no. 3-4, pp. 293-314, 2009.

[40] O. B. Christensen, M. Drews, and J. H. Christensen, "The HIRHAM regional climate model version 5," DMI Technical Report 06-17, 2006.

[41] L. O. Mearns, W. Gutowski, R. Jones et al., "A regional climate change assessment program for North America," Eos, vol. 90, pp. 311-312, 2009.

[42] C. G. Menéndez, M. de Castro, J.-P. Boulanger et al., "Downscaling extreme month-long anomalies in southern South America," Climatic Change, vol. 98, no. 3, pp. 379-403, 2010.
[43] F. Giorgi, C. Jones, and G. R. Asrar, "Addressing climate information needs at the regional level: the CORDEX framework," Bulletin of the World Meteorologic Organization, vol. 58, pp. 175183, 2009.

[44] D. P. Dee, S. M. Uppala, A. J. Simmons et al., “The ERA-Interim reanalysis: configuration and performance of the data assimilation system," Quarterly Journal of the Royal Meteorological Society, vol. 137, no. 656, pp. 553-597, 2011.

[45] G. Nikulin, C. Jones, F. Giorgi et al., "Precipitation climatology in an ensemble of CORDEX-Africa regional climate simulations," Journal of Climate, vol. 25, no. 18, pp. 6057-6078, 2012.

[46] J. Kim, D. E. Waliser, C. A. Mattmann et al., "Evaluation of the CORDEX-Africa multi-RCM hindcast: systematic model errors," Climate Dynamics, vol. 42, no. 5-6, pp. 1189-1202, 2014.

[47] L. Hernández-Díaz, R. Laprise, L. Sushama, A. Martynov, K. Winger, and B. Dugas, "Climate simulation over CORDEX Africa domain using the fifth-generation Canadian Regional Climate Model (CRCM5)," Climate Dynamics, vol. 40, no. 5-6, pp. 1415-1433, 2013.

[48] E. Gbobaniyi, A. Sarr, M. B. Sylla et al., "Climatology, annual cycle and interannual variability of precipitation and temperature in CORDEX simulations over West Africa," International Journal of Climatology, vol. 34, no. 7, pp. 2241-2257, 2014.

[49] J. B. Omotosho and B. J. Abiodun, "A numerical study of moisture build-up and rainfall over West Africa," Meteorological Applications, vol. 14, no. 3, pp. 209-225, 2007.

[50] B. J. Abiodun, Z. D. Adeyewa, P. G. Oguntunde, A. T. Salami, and V. O. Ajayi, "Modeling the impacts of reforestation on future climate in West Africa," Theoretical and Applied Climatology, vol. 110, no. 1-2, pp. 77-96, 2012.

[51] C. Kummerow, Y. Hong, W. S. Olson et al., "The evolution of the Goddard profiling algorithm (GPROF) for rainfall estimation from passive microwave sensors," Journal of Applied Meteorology, vol. 40, no. 11, pp. 1801-1840, 2001.

[52] G. J. Huffman, R. F. Adler, M. M. Morrissey et al., "Global precipitation at one-degree daily resolution from multisatellite observations," Journal of Hydrometeorology, vol. 2, no. 1, pp. 3650, 2001.

[53] G. T. Diro, D. I. F. Grimes, E. Black, A. O’Neill, and E. PardoIguzquiza, "Evaluation of reanalysis rainfall estimates over Ethiopia," International Journal of Climatology, vol. 29, no. 1, pp. 67-78, 2009.

[54] Z. T. Segele, L. M. Leslie, and P. J. Lamba, "Evaluation and adaptation of a regional climate model for the Horn of Africa: rainfall climatology and interannual variability," International Journal of Climatology, vol. 29, no. 1, pp. 47-65, 2009.

[55] Y. Wang, O. L. Sen, and B. Wang, "A highly resolved regional climate model (IPRC-RegCM) and its simulation of the 1998 severe precipitation event over China. Part I. Model description and verification of simulation," Journal of Climate, vol. 16, no. 11, pp. 1721-1738, 2003.

[56] B. Sultan, S. Janicot, and A. Diedhiou, "The West African monsoon dynamics. Part I: documentation of intraseasonal variability," Journal of Climate, vol. 16, no. 21, pp. 3389-3406, 2003.

[57] I. Diallo, M. B. Sylla, M. Camara, and A. T. Gaye, "Interannual variability of rainfall and circulation features over the Sahel based on multiple regional climate models simulations," Theoretical and Applied Climatology, vol. 113, no. 1-2, pp. 351-362, 2013.

[58] M. B. Sylla, I. Diallo, and J. S. Pal, "West African monsoon in state-of the-art regional climate models," in Climate 
Variability-Regional and Thematic Patterns, A. Tarhule, Ed., InTech, 2013.

[59] V. Moron and M. N. Ward, "ENSO teleconnections with climate variability in the European and African sectors," Weather, vol. 53, no. 9, pp. 287-295, 1998.

[60] F. H. M. Semazzi, V. Mehta, and Y. C. Sud, "An investigation of the relationship between sub-Saharan rainfall and global sea surface temperatures," Atmosphere-Ocean, vol. 26, no. 1, pp.118138, 1988.

[61] S. E. Nicholson and J. Kim, "The relationship of the El NiñoSouthern oscillation to African rainfall," International Journal of Climatology, vol. 17, no. 2, pp. 117-135, 1997.

[62] A. A. Akinsanola and K. O. Ogunjobi, "Analysis of rainfall and temperature variability over Nigeria," Global Journal of Human Social Sciences: Geography \& Environmental GeoSciences, vol. 14, no. 3, pp. 10-28, 2014.

[63] K. E. Taylor, "Summarizing multiple aspects of model performance in a single diagram," Journal of Geophysical Research D: Atmospheres, vol. 106, no. 7, pp. 7183-7192, 2001. 

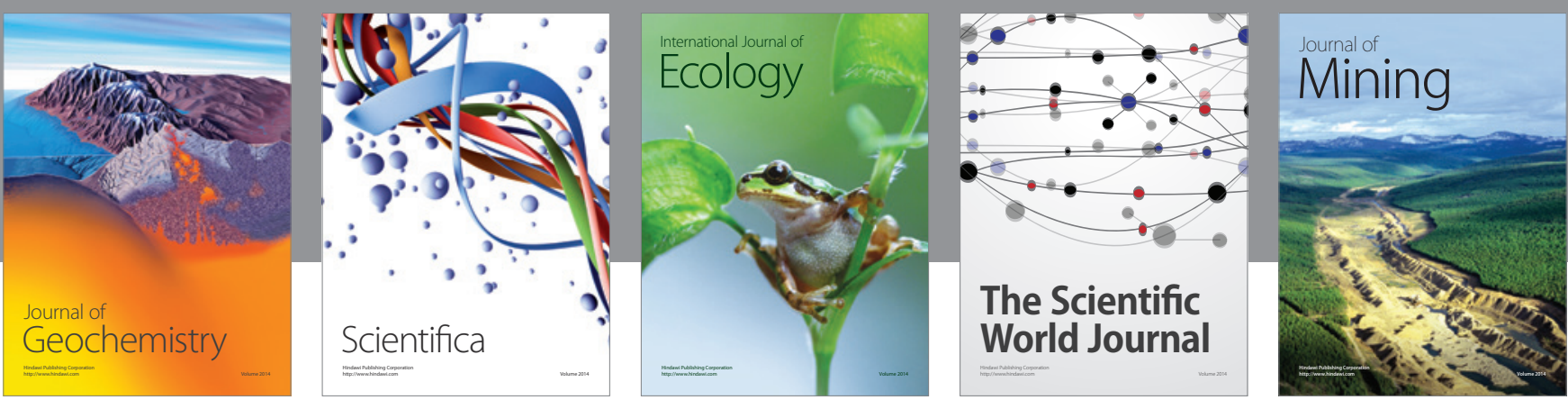

The Scientific World Journal
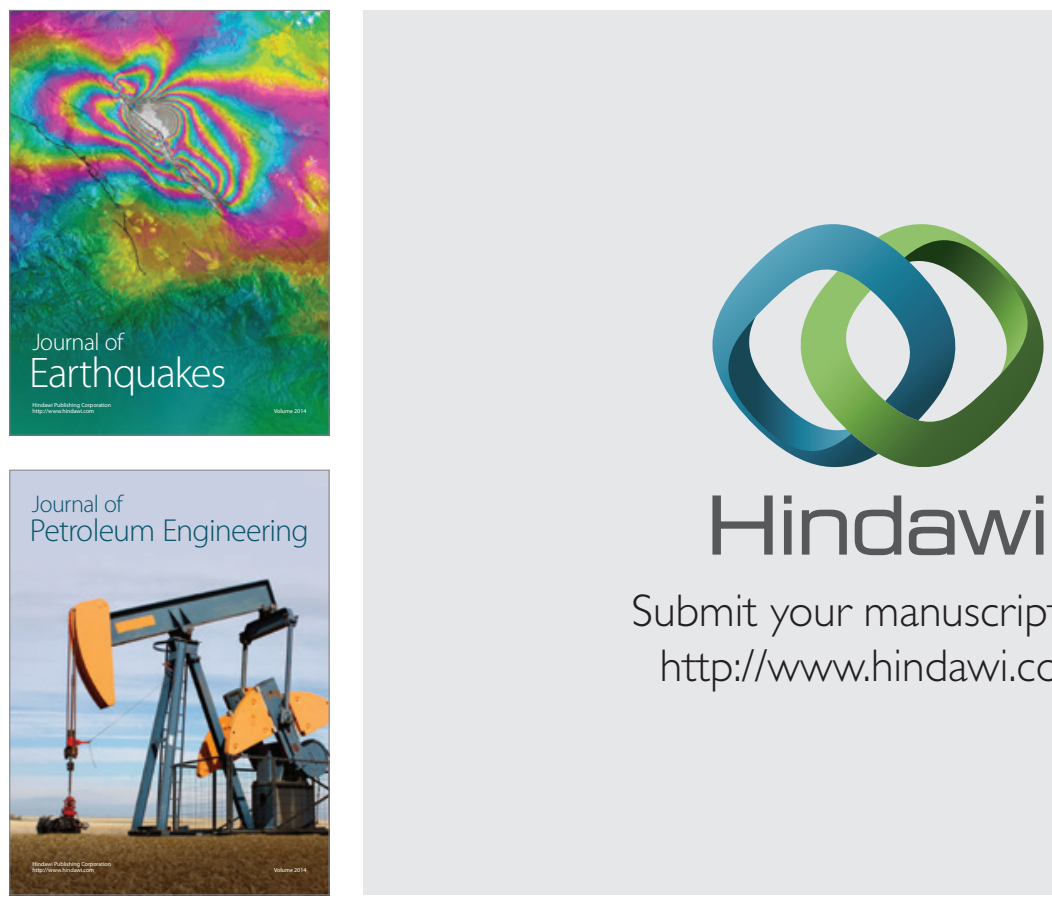

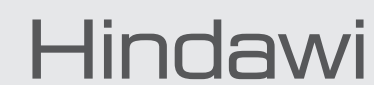

Submit your manuscripts at

http://www.hindawi.com
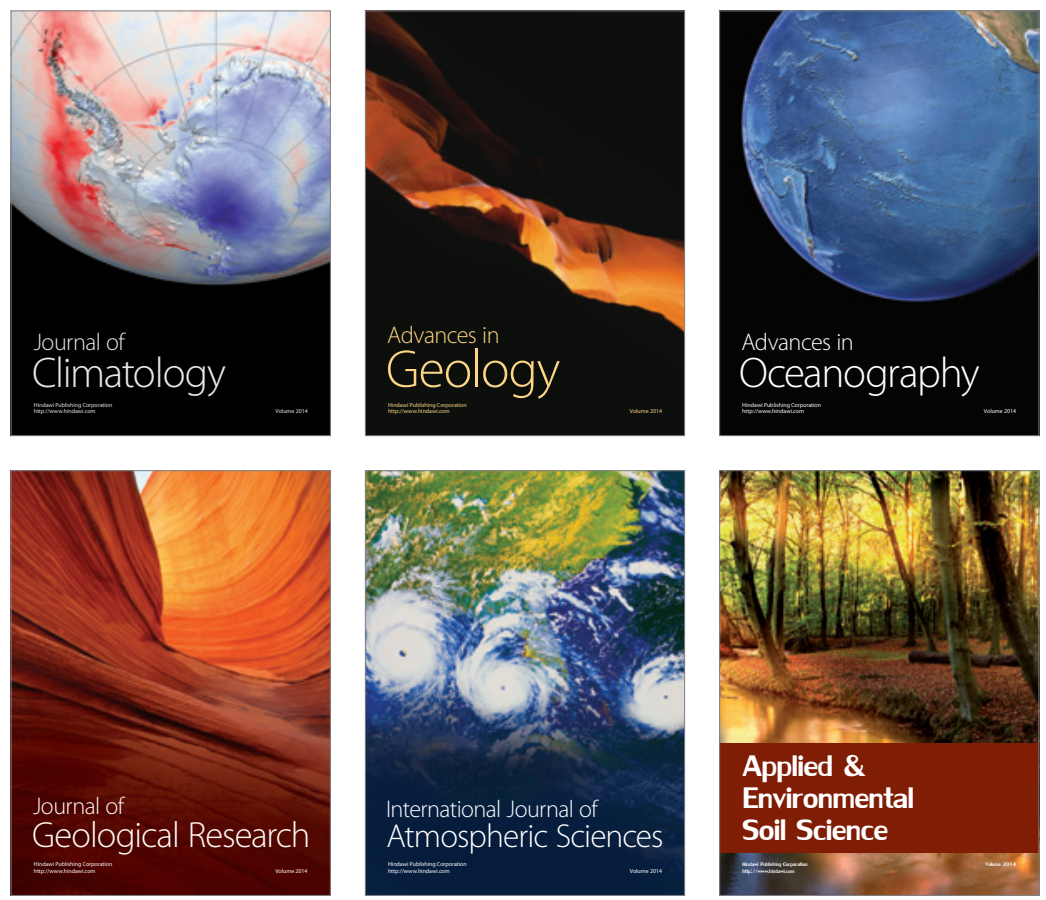
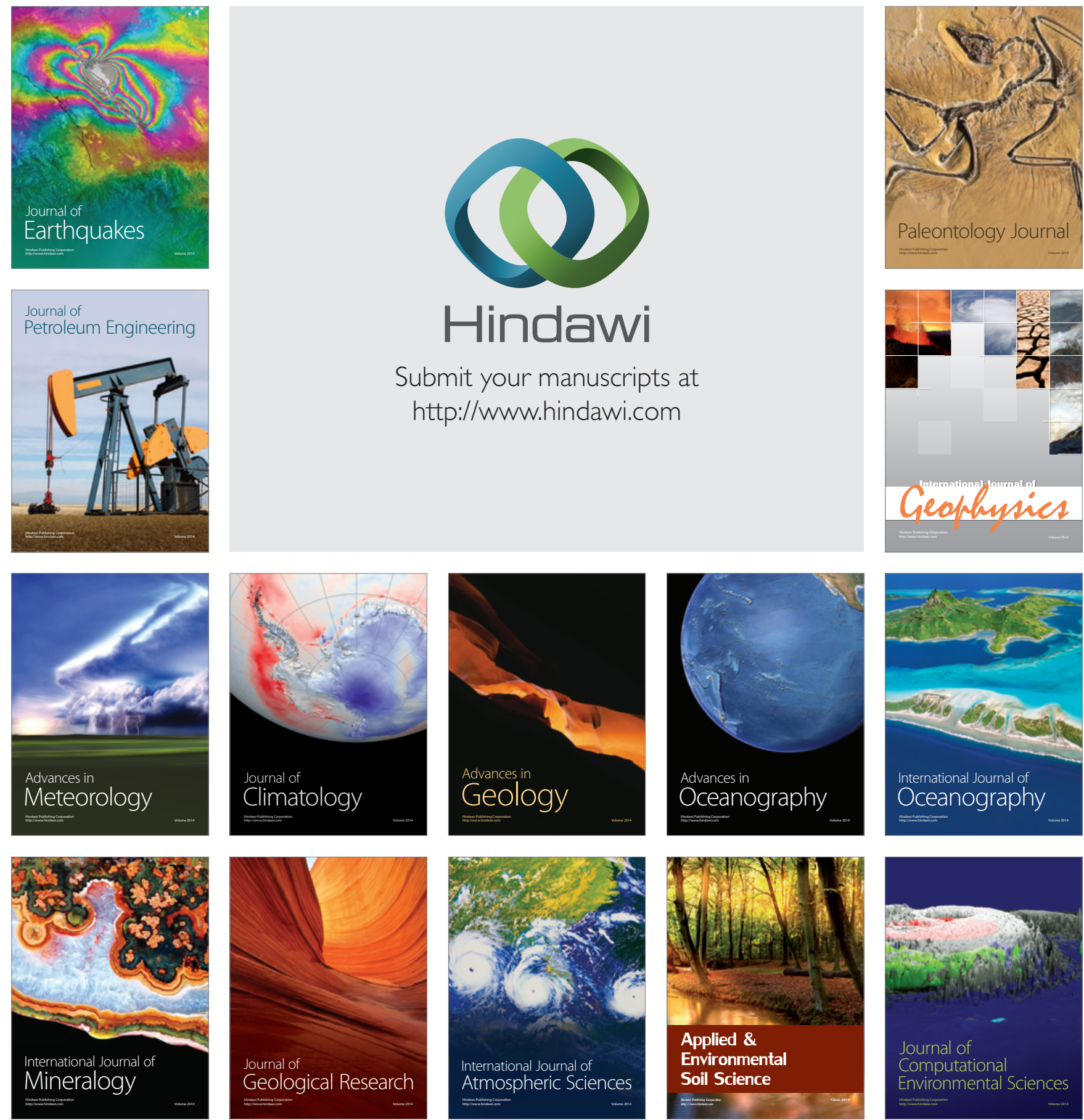